\title{
PRACE KAZUISTYCZNE
}

Aneta Kubisa ${ }^{1, A, B, D}$, Sylwia A. KrzemińsKa ${ }^{2, \text { C, E, F }}$

\section{Analiza problematyki uporczywej terapii $w$ intensywnej opiece pediatrycznej na przykładzie wybranych przypadków klinicznych}

\section{An Analysis of the Problems of Persistent Therapy in the Pediatric Intensive Care Based on Selected Clinical Cases}

${ }^{1}$ Oddział Anestezjologii i Intensywnej Terapii Noworodków i Dzieci, Wojewódzki Szpital Specjalistyczny im. J. Gromkowskiego we Wrocławiu, Wrocław

${ }^{2}$ Zakład Pielęgniarstwa Anestezjologicznego i Intensywnej Opieki, Uniwersytet Medyczny im. Piastów Śląskich we Wrocławiu, Wrocław

A - koncepcja i projekt badania; B - gromadzenie i/lub zestawianie danych; C - analiza i interpretacja danych;

D - napisanie artykułu; E - krytyczne zrecenzowanie artykułu; F - zatwierdzenie ostatecznej wersji artykułu

\begin{abstract}
Streszczenie
Problematyka terapii uporczywej wśród populacji dzieci budzi wiele niejasności i wywołuje dużo kontrowersji dotyczących wycofania się z procedur podtrzymujących życie. Podstawowa zasada w opiece pediatrycznej to zawsze działać w interesie dziecka, niezależnie od poglądów i postaw personelu czy rodziców. Terapia uporczywa wiąże się ze stosowaniem procedur medycznych w celu podtrzymania funkcji życiowych nieuleczalnie chorego, które przedłużają jego umieranie, wiążąc się z nadmiernym cierpieniem lub naruszeniem godności pacjenta. Na oddziale intensywnej terapii dziecięcej decyzje dotyczące zaprzestania leczenia podtrzymującego życie są podejmowane, ale nie zawsze. Decyzje o zaprzestaniu leczenia lub niepodejmowaniu resuscytacji powinny być podejmowane zespołowo. Istnieje problem w komunikacji personelu oraz etyczne i religijne wątpliwości dotyczące uporczywej terapii. Poważny problem stanowi brak dostępu do wsparcia psychologicznego, duchowego dla rodziny i personelu medycznego (Piel. Zdr. Publ. 2016, 6, 1, 77-80).
\end{abstract}

Słowa kluczowe: dzieci, intensywna terapia, uporczywa terapia.

\begin{abstract}
The problem of an ongoing treatment among the population a children raises a lot of confusion and controversies concerning the withdrawal of life-sustaining procedures. The basic principle in pediatric care is to always act in the best interest of a child, regardless of the views and attitudes of the staff and parents. Ongoing treatment is associated with medical procedures in order to maintain vital functions of terminally ill patients that prolong their dying, associated with excessive suffering or violation of the dignity of a patient. Decisions for termination of lifesustaining treatment in the Intensive Care Ward are not always taken. The decision to cease treatment or withhold resuscitation should be taken collectively. There is a staff communication problem and the ethical and religious concerns regarding the ongoing treatment. A major problem is the lack of access to psychological and spiritual support for families and medical personnel (Piel. Zdr. Publ. 2016, 6, 1, 77-80).
\end{abstract}

Key words: children, neonatal intensive care unit, persistent therapy.

Terapia uporczywa oznacza stosowanie procedur medycznych, urządzeń technicznych i środków farmakologicznych w celu podtrzymywania funkcji życiowych nieuleczalnie chorego, któ- re przedłużają jego umieranie. Stosowanie uporczywego leczenia w grupie dzieci wiąże się z nadmiernym cierpieniem, zadawaniem bólu, lękiem, brakiem poczucia bezpieczeństwa i intymności 
dziecka [1, 2]. Uporczywa terapia nie obejmuje podstawowych zabiegów pielęgnacyjnych, łagodzenia bólu i innych objawów oraz karmienia i nawadniania, o ile służą one dobru pacjenta [1]. Ochrona godności, dobra i praw dziecka nieuleczalnie, śmiertelnie chorego jest poważnym problemem etycznym we współczesnej pediatrii [2]. Uznanie prawa dziecka do godnej śmierci i zaprzestanie leczenia jest niezwykle trudne [1]. Dzieci śmiertelnie chore powinny być chronione przed bólem, cierpieniem oraz zbędnymi zabiegami leczniczymi i badaniami. Każde chore dziecko bez względu na rodzaj choroby podstawowej i stan psychofizyczny ma prawo do godności, szacunku oraz intymności. Dzieci powinny być informowane, stosownie do swojego wieku, o podejmowanych decyzjach dotyczących sprawowania nad nimi opieki [3].

Celem pracy była analiza problematyki uporczywej terapii $\mathrm{w}$ intensywnej opiece pediatrycznej na przykładzie wybranych przypadków klinicznych.

\section{Materiał i metody}

Badaniem objęto dwóch pacjentów Oddziału Anestezjologii i Intensywnej Terapii Noworodków i Dzieci, u których była stosowana uporczywa terapia. Jako metodę zastosowano studium indywidualnego przypadku. Techniką badawczą była obserwacja bezpośrednia oraz analiza dokumentacji medycznej.

\section{Przypadek 1}

3-letni chłopiec przyjęty na Oddział Anestezjologii i Intensywnej Terapii Noworodków i Dzieci po nagłym zatrzymaniu krążenia, do którego doszło w domu po zjedzeniu posiłku. Dziadek chłopca rozpoczął podstawowe zabiegi resuscytacyjne (BLS) i kontynuował do przyjazdu zespołu pogotowia ratunkowego. Podczas czynności resuscytacyjnych wystąpiły wymioty treścią pokarmową. Do chwili przyjęcia na oddział chłopiec był trzykrotnie defibrylowany $\mathrm{z}$ powodu zatrzymania krążenia w mechanizmie migotania komór. Czynności reanimacyjne trwały około 30 minut. Przy przyjęciu na oddział dziecko było ponownie resuscytowane przez zespół pogotowia.

Z wywiadu uzyskanego od matki dziecka: noworodek urodzony o czasie, drogą cięcia cesarskiego z powodu zagrażającego zakażenia wewnątrzmacicznego, u dziecka wystąpiły dotychczas 3 incydenty krótkotrwałej utraty przytomności. Chłopiec był poddany badaniom w celu rozpoznania padaczki, której nie stwierdzono.
Dziecko poddano intensywnej terapii, podano leki analgosedacyjne - fentanyl, midazolam oraz tiopental, zaintubowano, wentylowano mechanicznie w trybie oddechu kontrolowanego ze $100 \%$ tlenem. Układ krążenia niewydolny, chory wymagał podaży dużych dawek amin katecholowych, występowały zaburzenia rytmu serca, które leczono amiodaronem. W kolejnych dniach hospitalizacji występowały napady drgawkowe, w związku z czym dziecko otrzymywało Relanium. Włączono osłonowo antybiotyki: ceftriakson, metronidazol i diflukan. Dziecko nie reagowało na bodźce bólowe. Źrenice były szerokie, bez reakcji na światło. Wykonane dwukrotne badania tomografii komputerowej głowy wykazały zmniejszenie gęstości i zatarcie struktur mózgu na skutek ostrego niedotlenienia ośrodkowego układu nerwowego. Mimo intensywnego leczenia w 7 . dobie stan chłopca nie poprawił się. W 5. dobie po wykonaniu badania TK odstawiono analgosedację. Dziecko odżywiano dożylnie, pokarm doustny odstawiono ze względu na brak motoryki przewodu pokarmowego. Następowały kolejne incydenty migotania komór wymagające wielokrotnych defibrylacji. Po 10 dniach leczenia w wyniku analizy stanu klinicznego pacjenta i dokumentacji medycznej oraz rozmów $\mathrm{z}$ rodzicami terapia została ukierunkowana na leczenie paliatywne i intensywną pielęgnację dziecka.

Po 18 dniach leczenia przeprowadzono pierwszą serię prób potwierdzających śmierć mózgu. Badanie angiografii naczyń mózgowych wykazało brak krążenia mózgowego. Komisja lekarska ze względu na wątpliwość jednego z członków była powoływana dwukrotnie. Po 28 dniach intensywnego leczenia nastąpił zgon dziecka.

Każdego dnia dziecku od wczesnych godzin rannych do późnych wieczornych towarzyszyły osoby bliskie. Rodzice wraz z dziadkami chłopca czytali mu bajki, Biblię, wspominali okres radosnych wspólnie spędzonych chwil. Personel pielęgniarski wspierał bliskich chłopca. Personel medyczny uczestniczył we wszystkich trudnych sytuacjach. Wsparcia psychicznego rodzinie dziecka udzielał psycholog szpitalny oraz duchowny.

\section{Przypadek 2}

Niespełna 18-letni pacjent, u którego rozpoznano i leczono ciężką anemię plastyczną (SAA) został przyjęty z przewlekłą biegunką na Oddział Anestezjologii i Intensywnej Terapii Noworodków i Dzieci z powodu narastającej niewydolności wielonarządowej w przebiegu posocznicy.

Chłopiec był wcześniej leczony na oddziale hematologicznym, gdzie po raz drugi poddano go głębokiej immunosupresji i przeszczepowi komórek macierzystych. Po 5 dniach od przeszczepu do- 
szło do niewydolności nerek i zaistniała konieczność zastosowania hemodializy.

W czasie przyjęcia pacjent był cierpiący, lecz przytomny, w kontakcie słownym. Na skórze stóp, dłoni, a następnie całego ciała występowały obrzęki i zmiany krwotoczne. Na Oddziale Anestezjologii i Intensywnej Terapii Noworodków i Dzieci kontynuowano farmakoterapię wdrożoną na oddziale hematologii. Zmiany na skórze poszerzały się, tworząc pękające, krwotoczne, bolesne pęcherze. W 10. dobie leczenia wystąpiło krwawienie z układu pokarmowego z rozwiniętym wstrząsem krwotocznym. Stan pacjenta ustabilizował się po wielokrotnych przetoczeniach preparatów krwi i osocza. W 14. dobie z powodu narastającej ilości płynu w jamach opłucnowych wykonano obustronny drenaż opłucnowy. Mimo intensywnego leczenia stan pacjenta stopniowo się pogarszał. Narastająca niewydolność wielonarządowa wpłynęła na wycofanie się z intensywnego leczenia. Po konsultacji $z$ hematologami zrezygnowano $z$ leczenia ze względu na wyczerpanie możliwości leczenia przyczynowego. Utrzymywano analgosedację midazolamem i morfiną. Chłopiec oddychał samodzielnie, lecz bardzo cierpiał z powodu bólu.

Wszystkie czynności pielęgnacyjne były wykonywane $z$ pomocą kilku osób ze względu na dużą bolesność przy każdym dotyku. Terapia została przekierowana na leczenie paliatywne i intensywną pielęgnację. Pacjent do końca życia był przytomny, w logicznym kontakcie słownym. W rozmowie z personelem medycznym był nastawiony na walkę z chorobą. Do końca życia dziecka na życzenie rodziców nikt z chłopcem nie rozmawiał o umieraniu i śmierci. Rodzice towarzyszyli chłopcu każdego dnia. Po 18 dniach leczenia pacjent zmarł.

\section{Omówienie}

Problem wycofania lub niepodejmowania leczenia przedłużającego życie u ciężko chorego dziecka jest jednym z najtrudniejszych do rozwiązania [4]. W wielu beznadziejnych sytuacjach łatwiejsze jest dla lekarza stosowanie uporczywej terapii niż wycofanie się $\mathrm{z}$ niej. Decyzje dotyczące zaniechania i wycofania się $\mathrm{z}$ uporczywego leczenia podtrzymującego życie są podejmowane przez lekarzy w wielu placówkach leczniczych, chociaż nie we wszystkich. Zwiększająca się liczba dzieci leczonych przez hospicja domowe świadczy o zmianach i postępie dotyczącym postaw personelu terapeutycznego wobec rezygnacji $\mathrm{z}$ uporczywej terapii [2]. Jan Paweł II w encyklice Evangelium vitae w zdecydowany sposób odnosi się do zaprzestania uporczywego leczenia: „Kiedy lekarz zdaje sobie sprawę, że nie może już zapobiec śmierci pa- cjenta i że jedynym skutkiem intensywnej terapii byłoby pomnożenie jego cierpień, winien uznać ograniczoność wiedzy medycznej i swoich własnych działań, godząc się z nieuchronnością śmierci, której nie można się już przeciwstawić. Szacunek dla umierającej osoby stanowczo nakazuje wtedy unikać wszelkich form »terapii uporczywej« i dopomóc pacjentowi w akceptacji śmierci"[5]. Koncepcja praw dziecka dr. Janusza Korczaka postuluje 4 zasadnicze prawa dziecka:

„1) prawo dziecka do śmierci,

2) prawo dziecka do dnia dzisiejszego,

3) prawo dziecka, by było tym, czym jest,

4) prawo dziecka do wypowiadania swych myśli, czynnego udziału w naszych o nim rozważaniach i wyrokach" [6].

Royal Collage of Paediatrics and Child Health spośród sytuacji klinicznych wymienia tzw. sytuację „bez szans”, która uprawnia do wycofania się lub zaniechania terapii podtrzymującej życie [7].

Świadome kontynuowanie terapii daremnej w rozumieniu Europejskiej Konwencji o Ochronie Praw Człowieka i Podstawowych Wolności może stanowić pogwałcenie lub „nieludzkie i poniżające traktowanie”. Centrum Badań Opinii Społecznej opowiada się za rezygnacją z leczenia $\mathrm{w}$ sytuacji, kiedy wiadomo, że nie przyniesie spodziewanego rezultatu, a będzie wzmagać cierpienie i przedłuży umieranie chorego [8]. Badania wykazują, że aspekty religijne mają wpływ na stosunek do uporczywej terapii. Takie wnioski wysuwa K. Szewczyk w badaniach związanych z tożsamością religijną wśród lekarzy [9]. W badaniach D. Kochman i M. Guzy wykazano, że personel pielęgniarski również prezentuje pozytywną postawę wobec rezygnacji z niektórych procedur medycznych, by nie przysparzać cierpień i zapewnić dziec$\mathrm{ku}$ godne umieranie. Ankietowani w niniejszym badaniu uważają, że o zaprzestaniu stosowania uporczywej terapii powinna decydować grupa specjalistów. Na stosunek do uporczywej terapii mają wpływ względy religijne, światopogląd i względy etyczne wszystkich badanych pielęgniarek [10].

Z punktu widzenia etyki dla opiekunów dzieci ważną rolę odgrywa zasada szacunku wobec drugiej osoby, niekrzywdzenia, bezinteresowności, prawości, odpowiedzialności i czci dla życia, duże znaczenie ma jakość życia do jego końca. W opiece nad dziećmi ważna jest również rozmowa lekarza, pielęgniarki, psychologa, duchownego $\mathrm{z}$ rodzicami lub opiekunami nieuleczalnie chorego dziecka na temat zasadności stosowania uporczywej terapii. Dla każdego dziecka, a zwłaszcza dla śmiertelnie chorego obecność bliskich jest bardzo ważna. Decyzja o zaprzestaniu terapii jest bardzo trudną decyzją zarówno dla lekarza, jak i rodziny pacjenta. 


\section{Wnioski}

Współczesna medycyna skupia się na sukcesie terapeutycznym, dominuje w niej wiara w możliwości farmakoterapii i aparatury medycznej.

Personel medyczny nie ma ukształtowanych postaw, zwłaszcza wobec umierania dzieci i zachowań rodziców.

\section{Piśmiennictwo}

[1] Bołoz W., Krajnik M.: Konsensus Polskiej Grupy Roboczej ds. Problemów Etycznych Końca Życia. Definicja uporczywej terapii. Med. Paliat. Prakt. 2008, (2), 3, 77-78.

[2] Dangel T.: Zaniechanie i wycofanie się z uporczywego leczenia podtrzymującego życie u dzieci. Polskie Towarzystwo Pediatryczne: Wytyczne dla lekarzy. Warszawa 2011, 254-264.

[3] Karta Praw Dziecka Śmiertelnie Chorego w Domu. Rzecznik Praw Obywatelskich 2007. http://www.rpo.gov.pl/pliki/1196341986. pdf (dostęp do strony 2.09.2015).

[4] Nelson R.M.: Ethics in Pediatric Care, Nelson Textbook of Pediatrics. 2008, 3, 18-24.

[5] Jan Paweł II: Encyklika Evangelium vitae. Wydawnictwo Pallottinum, Rzym 1995.

[6] Korczak J.: Jak kochać dziecko. Prawo dziecka do szacunku. Wydawnictwo Akademickie „Żak”, Warszawa 2002.

[7] Baum D.: Zaniechanie i wycofanie się z leczenia podtrzymującego życie u dzieci. Zarys praktyki medycznej. Pediatr. Pol. 1999, 8, 821-837. http://www.hospicjum.waw.pl/img_in/Biblioteka/Zaniechanie_leczenia_p_z.pdf (dostęp do strony 5.09.2015).

[8] Rogulska B.: Aktualne problemy i wydarzenia. Komunikat z badań Centrum Opinii Społecznej, Warszawa 2013; www.cbos.pl. (dostęp do strony 19.08.2015).

[9] Szewczyk K.: Wybrane zagadnienia etyczne w opiece paliatywnej nad dziećmi. [W:] Pediatryczna opieka paliatywna. Red.: Korzeniewska-Eksterowicz A., Młynarski W. Uniwersytet Medyczny w Łodzi 2011, 463-471.

[10] Kochman D., Guza M.: Uporczywa terapia dzieci w opinii personelu pielęgniarskiego. Pielęgniarstwo XXI wieku 2014, 3(48).

\author{
Adres do korespondencji: \\ Aneta Kubisa \\ Oddział Anestezjologii i Intensywnej Terapii Noworodków i Dzieci \\ Wojewódzki Szpital Specjalistyczny im. J. Gromkowskiego \\ we Wrocławiu \\ ul. Koszarowa 5 \\ 51-149 Wrocław
}

Konflikt interesów: nie występuje

Praca wpłynęła do Redakcji: 10.11.2015 r.

Po recenzji: 8.03.2016 r.

Zaakceptowano do druku: 7.04.2016 r.

Received: 10.11 .2015

Revised: 8.03.2016

Accepted: 7.04.2016 